\title{
Influence of Biofertilizers on Plant Growth and Seed Yield of Pea (Pisum sativum L.)
}

\author{
Hukam Singh Kothyari", Lokesh Kumar Yadav, Rakesh Jat and Prakash Chand Gurjar \\ Department of Genetics and Plant Breeding and Seed Science and Technology, Sam \\ Higginbottom Institute of Agriculture, Technology and Sciences, Allahabad- 211007, U.P., India \\ *Corresponding author
}

\section{A B S T R A C T}

\begin{tabular}{|l|}
\hline Ke y w or d s \\
Azotobacter, \\
Rhizobium, PSB, \\
Growth parameters, \\
Seed yield, Pea. \\
\hline Article Info \\
\hline Accepted: \\
15 September 2017 \\
Available Online: \\
10 November 2017 \\
\hline
\end{tabular}

The present study was conducted to the Influence of biofertilizers on plant growth and seed yield of Pea (Pisum sativum L.). Based on the mean performance the Treatment- 8 $(100 \% \mathrm{RDF}+$ Rhizobium $200 \mathrm{gm} / \mathrm{kg}$ ) was found best treatment for plant growth and seed yield. This obtained high in plant height $(50.65 \mathrm{~cm})$, Number of branches per plant (13.75), Number of leaves per plant (33.10), days to $50 \%$ flowering (49.33), Number of pods per plant $(16.00)$, days to maturity $(81.00)$, Pod length $(8.10 \mathrm{~cm})$, Number of seed per pod (6.45), 100 seed weight (seed index) (17.45gm), seed yield per plant (17.35gm), Nodules per plant (21.95). Thus, it indicates that the process of seed treatment by biofertilizers may be better option for seed growers to achieve higher seed yield and yield attributes in pea. Biofertilizers are one of the most important tools in Agriculture for highest plant growth and seed production. Biofertilizers are prepared from live cells of different microorganisms and applied to soil, seed to the availability of nutrients and to improve fertility status of soil. Biofertilizers were found to be superior with regards to plant growth, and yield characters over control.

\section{Introduction}

Pulse crops have a specific importance for the vegetarian population of our country because pulses are the major source of protein. However, due to population explosion and low productivity of pulse crops, per capita availability of pulses is consistently decreasing. Per capita availability of pulses per day is only $47 \mathrm{~g}$ as against the minimum requirement of $104 \mathrm{~g}$ as recommended by nutritional experts of World Health Organization/Food and Agriculture Organization (Hariprasanna and Bhatt 2002).

Pea (Pisum sativum L.) is a cool season legume crop that is grown on over 25 million acres worldwide. Field pea or dry pea is marketed as a dry, shelled product for either human or livestock food. It is commonly used throughout the world in human diets and has high levels of amino acid, lysine and tryptophan, which are relatively low in cereal grains and contains approximately 21-25\% protein. Being a legume crop and has the inherent ability to obtain much of its nitrogen requirement from the atmosphere by forming a symbiotic relationship with Rhizobium bacteria in the soil (Schatz and Endres, 2009).

The favorable effect of Azotobacter and mineral nitrogen fertilizer on growth, 
chemical composition of leaves, and yield was reported on pea indicated that both inoculation with Azotobacter and application of $\mathrm{N}$ increased seed yield (Verma et al., 2000). A small dose of Biofertilizer is sufficient to produce desirable results because each gram of carrier of biofertilizers contains at least 10 million viable cells of a specific strain (Anandaraj and Delapierre, 2010).

Among the various fertilizers, biofertilizers are important sources of nutrients. Biofertilizers are natural fertilizers containing micro-organism which help in enhancing the productivity by Biological nitrogen fixation or solubilization of insoluble phosphate or producing hormones, vitamins and other growth regulators required for plant growth (Bhattacharya, 2000).

Rhizobium inoculation increased the root nodulation through better root development and more nutrient availability, resulting in vigorous plant growth and dry matter production which resulted in better flowering, fruiting and pod formation and ultimately there was beneficial effect on seed yield (Sardana et al., 2006).

The fixed phosphorus in the soil can be solubilized by phosphate solubilizing bacteria (PSB), which have the capacity to convert inorganic unavailable phosphorus form to soluble forms $\mathrm{HPO}_{4}{ }^{2-}$ and $\mathrm{H}_{2} \mathrm{PO}_{4}{ }^{-}$through the process of organic acid production, chelating and ion exchange reactions and make them available to plants. Therefore, the use of PSB in agricultural practice would not only offset the high cost of manufacturing phosphate fertilizers but would also mobilize insoluble in the fertilizers and soils to which they are applied (Chang and Yang, 2009) Keeping these facts the present investigation was undertaken to assess the effect of different biofertilizers on growth and yield characters of pea.

\section{Materials and Methods}

The research work was conducted at the experimental farm of Department of Genetics \& Plant breeding, Sam Higginbottom Institute of Agriculture, Technology and Sciences, Allahabad during the year 2015-2016.The experiment were carried out in Randomized block design with 10 treatments included Bio fertilizers (Azotobacter, Phosphorus Solubilizing Bacteria, Rhizobium). The following observations were recorded such as growth parameters Plant height $(\mathrm{cm})$, Number of leaves/plant, Days to $50 \%$ flowering, primary branch/plant, and Yield and yield characters, Number of pods per plant, seed yield per plant $(\mathrm{kg})$, No.of seed/pod, days to maturity, Nodules/plant. The Pea variety Azad matar-3 was selected for this research trial and seed source is Indian Institute of Pulse Research (IIPR) Kanpur (U.P.) India. The ten treatments were laid out in Randomized Block Design with three replications. The gross area of field is about $216.48 \mathrm{~m}^{2}$ and net area $120 \mathrm{~m}^{2}$ respectively. The fertilizer was applied at the time of sowing. Seeds were sown in line sowing method with $30 \mathrm{~cm}$ row to row spacing and $10 \mathrm{~cm}$ plant to plant spacing respectively. The soil of the experimental field was sandy loam and having $\mathrm{pH}$ 7.5. The recommended dose of nitrogen, phosphorus and potash was applied in all the plots except control. An optimum dose of nitrogen $\left(25 \mathrm{kgNha}^{-1}\right)$ was applied, half of which was given at the time of seed sowing along with the full dose of phosphorus $\left(60 \mathrm{~kg} \mathrm{ha}^{-1}\right)$ and potassium $\left(40 \mathrm{~kg} \mathrm{ha}^{-1}\right)$ and the remaining half dose of nitrogen was applied as top dressing. Recommended seed rate of 60-80 kg/ha. In the present study the seed treatment method was followed, in this case for each $\mathrm{kg}$ of seed, slurry was prepared by mixing and warming $200 \mathrm{~g}$ of bio-fertilizer culture i.e. Rhizobium, Azotobacter and phosphorus solubilizing bacteria (PSB) in 200 $\mathrm{ml}$ water containing $200 \mathrm{~g}$ Juggery and in 
interactional (co-inoculation) cases equal share of weight was taken from each member of the interaction corresponding to weight of $200 \mathrm{~g}$. The seed was kept for 15-20 minutes in slurry. After putting and taking out the seeds from the slurry after $15-20$ minutes, then they were spread in shade for $20-30$ minutes prior to their sowing in the prepared plots having size $(2.0 \times 2.0 \mathrm{~m})$ at $2.50 \mathrm{~cm}$ depth covering of furrows. The following treatment combinations were used in this research work such as $\mathrm{T}_{0}$ (control), $\mathrm{T}_{1}$ (100\%RDF + Azotobacter $100 \mathrm{~g} / \mathrm{kg}$ seed), $\mathrm{T}_{2}(100 \% \mathrm{RDF}+$ Rhizobium $100 \mathrm{~g} / \mathrm{kg}$ seed), $\mathrm{T}_{3}(100 \% \mathrm{RDF}+$ Phosphorus solubilizing bacteria $100 \mathrm{~g} / \mathrm{kg}$ seed), $\mathrm{T}_{4}(100 \% \mathrm{RDF}+$ Azotobacter $150 \mathrm{~g} / \mathrm{kg}$ seed), $\mathrm{T}_{5}(100 \% \mathrm{RDF}+$ Rhizobium $150 \mathrm{~g} / \mathrm{kg}$ seed), $\quad \mathrm{T}_{6} \quad(100 \% \mathrm{RDF}+$ Phosphorus solubilizing bacteria $150 \mathrm{~g} / \mathrm{kg}$ seed), $\mathrm{T}_{7}$ (100\%RDF + Azotobacter $200 \mathrm{~g} / \mathrm{kg}$ seed), $\mathrm{T}_{8}$ (100\%RDF + Rhizobium $200 \mathrm{~g} / \mathrm{kg}$ seed), $\mathrm{T}_{9}$ $(100 \% \mathrm{RDF}+$ Phosphorus solubilizing bacteria $200 \mathrm{~g} / \mathrm{kg}$ seed). The statistical analysis was carried out as per the methods suggested by Panse and Sukhatme (1967)

\section{Results and Discussion}

The result of revealed that the $\mathrm{T}_{8}$ application of $(100 \% \mathrm{RDF}+200 \mathrm{gm} / \mathrm{kg}$ seed $)$ were show significantly higher value on plant height, No. of seed/plant, No. of pods/plant, Days to 50\% flowering, Days to maturity, seed yield/plant, No. of seed/pod, No. of pods/plant followed by $\mathrm{T}_{9}$ with $(100 \% \mathrm{RDF}+\mathrm{PSB} 200 \mathrm{gm} / \mathrm{kg}$ seed $)$ while $\mathrm{T}_{0}$ with (control) was show minimum value for all these observations (Figs. 1-3).

\section{Effect on growth parameters}

In case of Days to 50\% flowering of pea it is evident from table 1 that significantly minimum days in Days to $50 \%$ flowering occurs by the $\mathrm{T}_{8}$ with application of $100 \%+$ Rhizobium @ 200 g/kg seed may be considered as the best treatment for early duration in days to $50 \%$ (49.33 days), followed by $\mathrm{T}_{7}$ with $100 \%+$ Azotobacter $200 \mathrm{gm} / \mathrm{kg}$ seed (50.00 days) and Maximum days was occured in $\mathrm{T}_{0}$ with control (53.33 days). Similar results were reported by Dekhane et al., (2011) conducted the cowpea seeds inoculated with Rhizobium significantly increased the growth parameters and yield attributes recorded by seed inoculation with $100 \%$ RDF+ Rhizobium. Kanaujia et al., (1997) also reported that pea seed inoculation with Rhizobium culture attributed to higher number of nodules/plant at all the stages (45, 90 and 135 days after sowing) of plant growth, and this increase in nodulation and nitrogen fixation due to the inoculation led to significantly more plant height, days taken to flowering, higher green pod yield and dry matter over un-inoculated control.

In case of Plant height of pea it is evident from table 1 that significantly maximum increase in plant height occurs by the $\mathrm{T}_{8}$ with application of 100\% RDF + Rhizobium 200g/ $\mathrm{kg}$ Seed recorded high plant height $(50.65 \mathrm{~cm})$, followed by $\mathrm{T}_{9}$ with $100 \%+\mathrm{PSB}$ $200 \mathrm{gm} / \mathrm{kg}$ seed $(50.30 \mathrm{~cm})$ and Minimum value was obtained in $\mathrm{T}_{0}$ with control $(42.20 \mathrm{~cm})$. Similar results were reported by Dekhane et al., (2011) reported that the inoculation of pea seeds with Rhizobium was responsible for significant increments on plant height, number of leaves and branches, fresh and dry weight plant-1 and dry matter \%, compared to the un-inoculated plants. Rather et al., (2010) also find out the effect of biofertilizers (Rhizobium, Azotobacter and phosphate solubilizing bacteria (PSB)) application on growth, yield and economics of field pea (Pisum sativum L.). The coinoculation of all the three bio-fertilizers i.e. Rhizobium, Azotobacter and PSB produced significantly higher growth characters as compared to absolute control and when inoculated them individually. The treatment $\mathrm{T}_{8}$ comprising Rhizobium + Azotobacter + 
PSB gave highest growth in terms of plant height $(45.26 \mathrm{~cm})$, number of branches/ plant (4.20), number of leaves/ plant. Sharma and Chauhan (2011) reported that $100 \%$ NPK + Vermicompost + Biofertilizers gave the maximum plant height of $72.83 \mathrm{~cm}$ which was statistically significant over all other treatments.

In case of branches per plant of pea it is evident from table 1 that significantly maximum increase in branches per plant occurs by $_{8}$ with the application of $100 \%$ $\mathrm{RDF}+$ Rhizobium @ 200 g/ kg seed exhibited higher mean value for number of branches (13.75), followed by $\mathrm{T}_{9}$ with $100 \%+$ PSB $200 \mathrm{gm} / \mathrm{kg}$ seed (13.35) and Minimum value was obtained in $\mathrm{T}_{0}$ with control (11.65). Similar findings have been reported by Dekhane et al., (2011), and Sarg and Hassan (2003) reported on pea plant, that plant height, leaves and branches number /plant and number of nodules were significantly increased with Rhizobium inoculation compared with the un-inoculated one.

In case of Leaves per plant of pea it is evident from table 1 that significantly maximum increase in Leaves per plant occurs by $\mathrm{T}_{8}$ with application of 100\% RDF + PSB @ 200 g/ kg seed exhibited higher mean value for number of leaves per plant (33.10), followed by $\mathrm{T}_{9}$ with $100 \%$ + PSB 200gm/kg seed (32.40) and Minimum value was obtained in $\mathrm{T}_{0}$ with control (30.45). Similar results were reported by Rather et al., (2010), and Dekhane et al., (2011) and also Solieman et al., (2003) on pea plant, that inoculation of pea seeds with Rhizobium significantly increased plant height, number of branches/plant compared to the un-inoculated one.

In case of Days to maturity of pea it is evident from table 1 that significantly minimum days in Days to maturity occurs by the $\mathrm{T}_{8}$ with application of $100 \%$ RDF + Rhizobium @ $200 \mathrm{~g} / \mathrm{kg}$ seed recorded best treatment for days to maturity (81.00), followed by $\mathrm{T}_{9}$ with $100 \%$ + PSB 200gm/kg seed (82.00) and Minimum value was obtained in $\mathrm{T}_{0}$ with control (84.65).

\section{Effect on yield and yield attributes}

In case of Number of seed per pod of pea it is evident from table 1 that significantly maximum increase in Number of seed per pod occurs by $\mathrm{T}_{8} 100 \%$ RDF + Rhizobium @ 200 $\mathrm{g} / \mathrm{kg}$ seed exhibited high number of seeds per pod (6.45), followed by $\mathrm{T}_{9}$ with $100 \%+\mathrm{PSB}$ $200 \mathrm{gm} / \mathrm{kg}$ seed (5.75) and Minimum value was obtained in $\mathrm{T}_{0}$ with control (4.80). Similar findings have been reported by Mishra et al., (2010) also reported to the effect of biofertilizers in conjunction with inorganic fertilizers on growth and yield of dwarf field pea (cv. Jai) and found that number of pods plant ${ }^{-1}$, number of seeds pods $^{-1}$ at maturity attributed significantly increasing with the application of $100 \%$ DRF and seed inoculation of Rhizobium + PSB + PGPR.

In case of Seed index of pea it is evident from table 1 that significantly maximum increase in Seed index occurs by the treatment $8\left(\mathrm{~T}_{8}\right.$ 100\% RDF + Rhizobium @ 200 g/kg seed) exhibited high seed index (17.45gm), followed by $\mathrm{T}_{9}$ with $100 \%+$ PSB $200 \mathrm{gm} / \mathrm{kg}$ seed $(16.90 \mathrm{gm})$ and Minimum value was obtained in $\mathrm{T}_{0}$ with control (15.90gm). Similar results were reported by Dekhane et al., (2011) reported on pea plant, that Seed index and number of nodules were significantly increased with Rhizobium inoculation compared with the un-inoculated one. In case of Pod length of pea it is evident from table 1 that significantly maximum increase in Pod length occurs by the $\mathrm{T}_{8}(100 \% \mathrm{RDF}+$ Rhizobium @200 g/ kg seed) exhibited high for pod length $(8.10 \mathrm{~cm})$, followed by $\mathrm{T}_{9}$ with $100 \%+$ PSB $200 \mathrm{gm} / \mathrm{kg}$ seed $(8.00 \mathrm{~cm})$ and Minimum value was obtained in $\mathrm{T}_{0}$ with control $(7.15 \mathrm{~cm})$. 


\section{Int.J.Curr.Microbiol.App.Sci (2017) 6(11): 1810-1817}

Table.1 Mean performance of biofertilizers on plant growth and seed yield of pea

\begin{tabular}{|c|c|c|c|c|c|c|c|c|c|c|c|c|}
\hline Sr. No. & Treatments & $\begin{array}{c}\mathbf{5 0 \%} \\
\text { Flowering } \\
\text { (Days) }\end{array}$ & $\begin{array}{c}\text { Plant } \\
\text { height } \\
(\mathrm{cm})\end{array}$ & $\begin{array}{c}\text { No. of } \\
\text { Branches } \\
\text { /plant }\end{array}$ & $\begin{array}{c}\text { No. of } \\
\text { Leaves/ } \\
\text { plant }\end{array}$ & $\begin{array}{c}\text { No. of } \\
\text { Pods/ } \\
\text { plant }\end{array}$ & $\begin{array}{c}\text { Days of } \\
\text { maturity } \\
\text { (Days) }\end{array}$ & $\begin{array}{c}\text { Pod } \\
\text { length } \\
(\mathrm{cm})\end{array}$ & $\begin{array}{l}\text { No. of } \\
\text { Seed } \\
\text { /pod }\end{array}$ & $\begin{array}{c}100 \text { seed } \\
\text { weight } \\
(\mathrm{gm})\end{array}$ & $\begin{array}{l}\text { Seed yield/ } \\
\text { plant }(\mathrm{gm})\end{array}$ & $\begin{array}{l}\text { Nodules } \\
\text { /plant }\end{array}$ \\
\hline 1. & $\mathrm{~T}_{0}=$ Control & 53.33 & 42.20 & 11.65 & 30.45 & 10.75 & 84.65 & 7.15 & 4.80 & 15.90 & 14.55 & 12.60 \\
\hline 2. & $\mathrm{~T}_{1}=\mathrm{RDF}+$ Azotobacter $(100 \mathrm{gm} / \mathrm{kg}$ seed $)$ & 51.65 & 43.15 & 11.80 & 31.26 & 13.25 & 83.00 & 7.90 & 5.45 & 16.50 & 14.95 & 14.35 \\
\hline 3. & $\mathrm{~T}_{2}=\mathrm{RDF}+$ Rhizobium $(100 \mathrm{gm} / \mathrm{kg}$ seed $)$ & 52.60 & 44.45 & 12.55 & 30.95 & 13.00 & 84.00 & 7.60 & 5.20 & 16.35 & 15.20 & 14.95 \\
\hline 4. & $\begin{array}{l}\mathrm{T}_{3}=\mathrm{RDF}+\text { Phosphate solubilising bacteria }(100 \\
\mathrm{gm} / \mathrm{kg} \text { seed })\end{array}$ & 53.00 & 45.30 & 12.20 & 31.65 & 13.90 & 83.65 & 7.40 & 5.30 & 16.70 & 15.80 & 15.20 \\
\hline 5. & $\mathrm{~T}_{4}=\mathrm{RDF}+$ Azotobacter $(150 \mathrm{gm} / \mathrm{kg}$ seed $)$ & 51.00 & 45.35 & 12.06 & 30.75 & 12.90 & 82.65 & 7.35 & 5.15 & 16.65 & 15.55 & 16.55 \\
\hline 6. & $\mathrm{~T}_{5}=\mathrm{RDF}+$ Rhizobium $(150 \mathrm{gm} / \mathrm{kg}$ seed $)$ & 50.33 & 46.90 & 13.00 & 32.00 & 13.15 & 83.30 & 7.70 & 5.25 & 16.60 & 16.00 & 18.05 \\
\hline 7. & $\begin{array}{l}\mathrm{T}_{6}=\mathrm{RDF}+\text { Phosphate solubilising bacteria }(150 \\
\mathrm{gm} / \mathrm{kg} \text { seed })\end{array}$ & 51.33 & 47.55 & 13.25 & 30.80 & 13.70 & 82.30 & 7.75 & 5.40 & 16.15 & 15.90 & 18.00 \\
\hline 8. & $\mathrm{~T}_{7}=\mathrm{RDF}+$ Azotobacter $(200 \mathrm{gm} / \mathrm{kg}$ seed $)$ & 50.00 & 44.65 & 11.85 & 30.85 & 14.60 & 84.30 & 7.50 & 5.60 & 16.70 & 15.75 & 18.80 \\
\hline 9. & $\mathrm{~T}_{8}=\mathrm{RDF}+$ Rhizobium $(200 \mathrm{gm} / \mathrm{kg}$ seed $)$ & 49.33 & 50.65 & 13.75 & 33.10 & 16.00 & 81.65 & 8.10 & 6.45 & 17.45 & 17.35 & 21.95 \\
\hline 10. & $\begin{array}{l}\mathrm{T}_{9}=\mathrm{RDF}+\text { Phosphate solubilising bacteria }(200 \\
\mathrm{gm} / \mathrm{kg} \text { seed })\end{array}$ & 52.66 & 50.30 & 13.35 & 32.40 & 14.75 & 82.00 & 8.00 & 5.75 & 16.90 & 16.30 & 20.60 \\
\hline 11. & Mean & 51.52 & 46.05 & 12.54 & 31.42 & 13.60 & 83.15 & 7.64 & 5.43 & 16.59 & 15.73 & 17.10 \\
\hline 12. & S.Em & 1.00 & 1.44 & 0.25 & 0.75 & 1.30 & 0.67 & 0.16 & 0.27 & 0.28 & 0.15 & 0.56 \\
\hline 13. & C.D. $5 \%$ & 2.97 & 4.30 & 0.74 & 2.23 & 3.87 & 2.00 & 0.48 & 0.82 & 0.83 & 0.47 & 1.67 \\
\hline
\end{tabular}


Fig.1 Histogram depicting the effect of treatments on plant height $(\mathrm{cm})$ in pea

\section{Plant height $(\mathrm{cm})$}

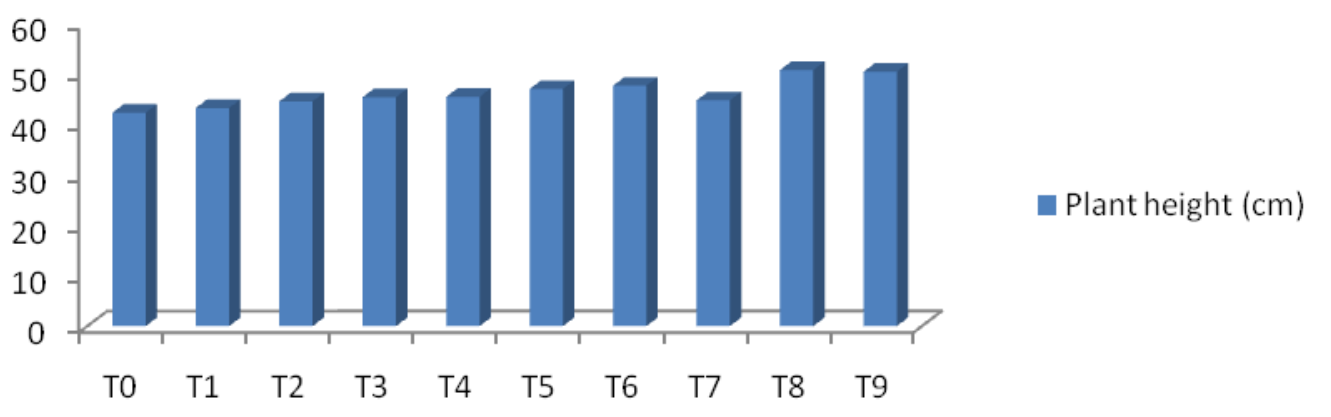

Fig.2 Histogram depicting the effect of treatments on seed index $(\mathrm{g})$ in pea

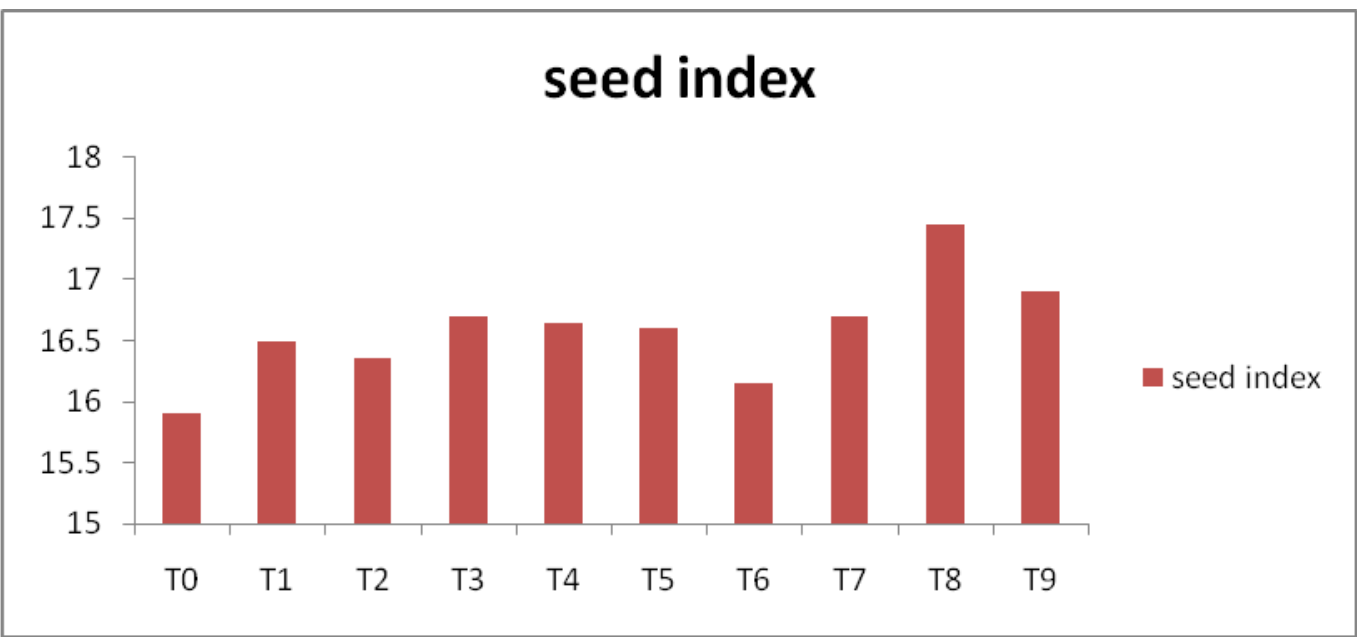

Fig.3 Histogram depicting the effect of treatments on seed yield / plant (g) in pea

\section{seed yield / plant (gm)}

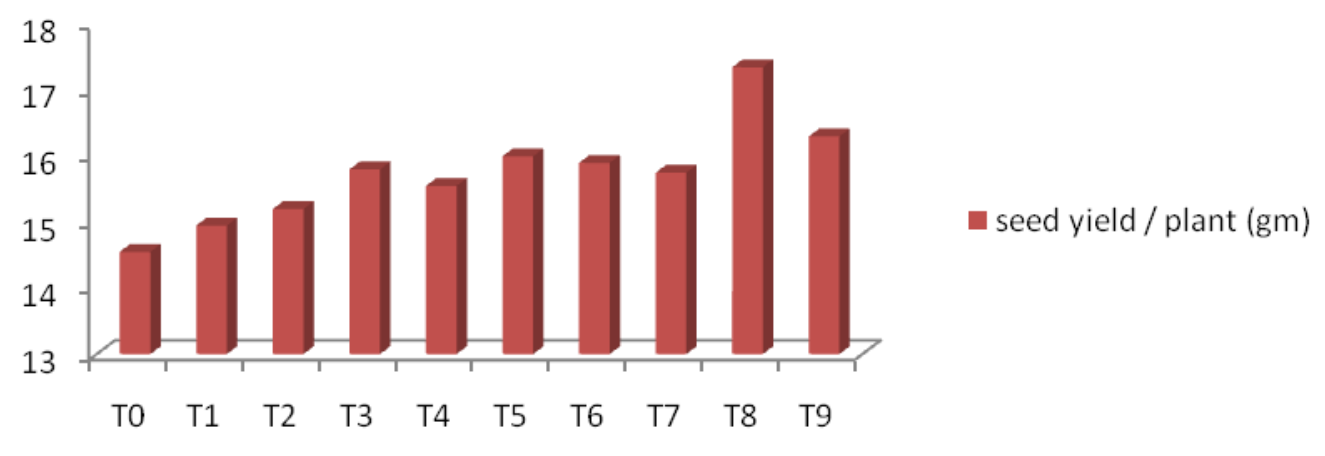


Similar observations were reported by Dekhane et al., (2011) reported on pea plant, that plant height, pod length, and number of nodules were significantly increased with Rhizobium inoculation compared with the un-inoculated one. In case of Seed yield per plant of pea it is evident from table 1 that significantly maximum increase in Seed yield per plant occurs by the $\mathrm{T}_{8}$ with application of (100\% RDF + Rhizobium @ $200 \mathrm{~g} / \mathrm{kg}$ seed) exhibited high seed yield per plant $(17.35 \mathrm{gm})$, followed by $\mathrm{T}_{9}$ with $100 \%+$ PSB $200 \mathrm{gm} / \mathrm{kg}$ seed $(16.30 \mathrm{gm})$ and Minimum value was obtained in $\mathrm{T}_{0}$ with control (14.55gm). Similar observations were reported by Kanaujia et al., (1997) revealed that seed inoculation of Rhizobium @ $30 \mathrm{~g} / \mathrm{kg}$ seed along with $30 \mathrm{~N} / \mathrm{ha}$ as basal application in broad bean have produced highest number of nodules/plant and Treatment also recorded maximum number of pods per plant (14.78) and seed yield $(22.10 \mathrm{q} / \mathrm{ha})$ but failed to produce any significant influence on the number of seeds/pods seed weight.

In case of Nodules per plant of pea it is evident from table 1 that significantly maximum increase in Nodules per plant occurs by the $T_{8}$ (100\% RDF + Rhizobium @ 200 g/ kg seed) exhibited high number of nodules per plant (21.95), followed by $\mathrm{T}_{9}$ with $100 \%+\mathrm{PSB}$ $200 \mathrm{gm} / \mathrm{kg}$ seed (20.60) and Minimum value was obtained in $\mathrm{T}_{0}$ with control (12.60). Similar findings have been reported by Gupta and Namdeo (1999), Prasad et al., (2002) and Sarg and Hassan et al., (2003), observed a significant increase in number of nodule/plant in pea crop, when organic amendments and bio-fertilizers are both applied in together combination and also reported by Ramadan (1997) indicated that seed inoculation with Rhizobium, revealed significant effect on all studied morphological characters; i.e. stem length $(\mathrm{cm})$, number of branches, number of leaves and number of nodules/plant compared to un-treated one (control).

In case of Pods per plant of pea it is evident from table 1 that significantly maximum increase in Pods per plant by the $\mathrm{T}_{8}(100 \% \mathrm{RDF}$
+ Rhizobium @200 g/ kg seed) exhibited higher mean value for number of pods per plant (16.00), followed by $\mathrm{T}_{9}$ with $100 \%+$ PSB $200 \mathrm{gm} / \mathrm{kg}$ seed (14.75) and Minimum value was obtained in $\mathrm{T}_{0}$ with control (10.75).

Similar findings have been reported by ElMansi et al., (2000) showed that seed inoculation with Rhizobium gave significantly higher values of pod number/plant and total yield/fed compared with check. Mishra et al., (2010) also reported to the effect of biofertilizers in conjunction with inorganic fertilizers on growth and yield of dwarf field pea (cv. Jai) and found that number of pods plant-1, number of seeds pods-1 at maturity attributed significantly increasing with the application of $100 \%$ DRF and seed inoculation of Rhizobium + PSB + PGPR.

The above results showed that the integration of biofertilizers along with chemicals has a positive effect on the plant growth and yield attributes of pea. It is concluded from the present investigation that treatment $\mathrm{T}_{8}(100 \%$ RDF + Rhizobium $200 \mathrm{~g} / \mathrm{kg}$ of seed) exhibited higher mean value for seed yield per plant, number of primary branches, number of leaves per plant, number of pods per plant, pod length, number of seeds per pod, plant height, seed yield per plant, seed index and nodules per plant followed by $\mathrm{T}_{9}(100 \% \mathrm{RDF}+\mathrm{PSB} 200 \mathrm{gm} / \mathrm{kg}$ seed) and minimum value for these characters showed in control. $\mathrm{T}_{0}$ with control showed more days to $50 \%$ flowering, $\mathrm{T}_{8}$ (RDF + Rhizobium @ $200 \mathrm{~g} / \mathrm{kg}$ seed) recorded best treatment for days to early maturity and early flowering. Thus, it indicates that the process of seed treatment by biofertilizers may be better option for seed growers to achieve higher seed yield and yield attributes in pea.

\section{References}

Anandaraj, B and L.R.A. Delapierre, (2010) Studies on influence of bioinoculants (Pseudomonas fluorescens, Rhizobium sp., Bacillus megaterium) in green gram, 
Journal of Bio science Technology, 1(2): 95-99.

Bhattacharya, S. K. (2000) Current facets in potato research Proceed Souvenir and Abstracts, National Seminar, Indian Potato Association, C.P.R.S., Modipuram Mcerut, Dec. 13-15. pp. 8-9.

Chang C.H. and Yang S.S. (2009) Thermotolerant phosphate-solubilizing microbes for multi-functional biofertilizer preparation, Bioresearch and Technology, 100: 1648-1658.

Dekhane, S.S. and Chavan, A.S. (2011) Yield and yield attributing characters of cowpea as influenced by biofertilizers and fertility levels cv. GC-4, Advance Research Journal of Crop Improvement, 2 (1): 31-34.

El-Mansi AA, Bardisi A, and El-Atabany SA (2000) Effect of Rhizobium and soil plastic mulch on nodulation, plant growth and yield of pea under sandy soil conditions, Zagazig Journal of Agricultural Research, 27(4): 899-912.

Gupta, S. C. and Namdeo, S. L. (1999) Fertilizer economy through organic manures and Rhizobium inoculation in pigeonpea, Journal of Crop Research, (Hisar), 18(1): 34-38.

Hariprasanna, K. and Bhatt J. (2002) Pulses production looking at constraints and prospects, Agriculture today,49-53.

Kanaujia, S. P. Restogi, K. B. and SK Sharm, (1997) Effect of phosphorus, potassium and rhizobium inoculation on growth, yield and quality of pea cv. Lincolin. Journal of Vegetable Science, 24(2): 91-94.

Mishra A, Prasad K and Rai G (2010) Effect of Bio-fertilizer Inoculations on Growth and Yield of Dwarf Field Pea (Pisum sativum L.) in Conjunction with Different Doses of Chemical Fertilizers, Journal of Agronomy,9:163-168.
Panse and Sukhatme, (1967) Statistical Analysis of variance

Prasad, et al., (2002) Synergism among phosphate solublizing bacteria, rhaizobacteria and Rhizobium in urdbean, Indian Journal of Pulses Reaserch, 15(2): 131-135.

Ramadan, MM (1997) Effect of some agricultural treatments on the growth and yield of pea plant, M.Sc. Thesis, Faculty of Agriculure, Zagazig University, Egypt.

Rather SA, Hussain MH and Sharma, ML (2010) Effect of biofertilizers on growth yield and economics of field pea (Pisum sativum L.), International Journal ofAgricultural Science, 6(1): 65-66.

Sardana V, Sheoram P and Singh S. (2006) Indian Journal of Pulses Research, 19: 216.

Sarg MHS and Hassan MAH (2003) Effect of Rhizobium inoculation, nitrogen fertilization and plant densityon growth, yield and minerals content of pea undersandy soil conditions, Journal of Agricultural Science, Mansoura. University, 28(11): 6857-6873.

Schatz, B. and G. Endres, 2009 Pea production North Dakota State University, Fargo, USA

Sharma U and Chauhan JK (2011) Influence of integrated use of inorganic and organic sources of nutrients on growth and production of pea, Journal of farm science, 1(1):14-18.

Solieman THI, El-Khatib HA and El-Araby SM (2003) Effect of organic manure, mineral nitrogen and biofertilizer application on vegetative growth and chemical composition of pea (Pisum sativum, L.), Zagazig Journal of Agricultural Research, 30 (3): $751-767$.

Verma O.P., P. Sangeeta, M.S. Rathi and S. Paul, (2000) Synergistic effect of co-inoculation of Azotobacter chrooccum and Rhizobium on pea (Pisum sativum).

\section{How to cite this article:}

Hukam Singh Kothyari, Lokesh Kumar Yadav, Rakesh Jat and Prakash Chand Gurjar. 2017. Influence of Biofertilizers on Plant Growth and Seed Yield of Pea (Pisum sativum L.). Int.J.Curr.Microbiol.App.Sci. 6(11): 1810-1817. doi: https://doi.org/10.20546/ijcmas.2017.611.216 